\title{
EFFECTS OF THYROTROPIN-RELEASING HORMONE IN DEPRESSION*
}

\author{
A. J. Prange, JR. $\quad$ I. C. WILSON \\ P. P. LARA \\ L. B. Alltop \\ G. R. BREESE
}

Department of Psychiatry, Medical School, University of North Carolina, Chapel Hill;

Biological Sciences Research Center; and Division of Research, North Carolina Mental Health

Department, North Carolina, U.S.A.

Summary Ten euthyroid women with unipolar depression were treated with a single injection of thyrotropin-releasing hormone (T.R.H.) and a single injection of saline in a double-blind, crossover comparison. T.R.H. caused a prompt, brief improvement in depression without causing significant side-effects Most patients showed a reduced thyrotropin (T.S.H.) response to T.R.H. injection, though none had abnormal thyroid function tests or clinical findings suggesting pituitary or thyroid disease.

\section{Introduction}

THYROTROPIN-RELEASING hormone (T.R.H.), a substance of hypothalamic origin, is a potent and nontoxic stimulator of pituitary thyrotropin (T.S.H.) ${ }^{1,2}$ and pituitary prolactin 3,4 in man. Our interest in T.R.H. (or any agent that would cause T.S.H. release) stems from our work demonstrating that L-triiodothyronine (T3) will potentiate the antidepressant effects of tricyclic drugs in women. ${ }^{5-11}$ Further work by our group indicated that T.S.H. also potentiates tricyclic antidepressants, presumably by causing release of thyroid hormones. ${ }^{12,13}$

These findings prompted us to examine the psychopharmacological effects of T.R.H. in animals. With N. P. Plotnikoff, we investigated the activity of T.R.H. in the pargyline/L-dopa potentiation test, which has been used to screen drugs for antidepressant potential. ${ }^{14}$ T.R.H. was active in this test and, surprisingly, was equally active in intact and hypophysectomised mice. ${ }^{15}$ These data suggest that L-dopa potentiation by T.R.H. in animals is not mediated via increased secretion of T.S.H. or thyroid hormones and that an extrapituitary mechanism is at work. Although this study did not clarify the mechanisms for our earlier findings, 
it did suggest that T.R.H. might have antidepressant activity. We present here our observations on eighteen depressed women who were treated with intravenous T.R.H.

To discern proper dose and possible toxicity, we studied eight women with unipolar depression in a flexible single-blind study. A single intravenous injection of T.R.H., from 200 to $800 \mu \mathrm{g}$., seemed sufficient to cause prompt, brief, clinical improvement. 500-600 $\mu \mathrm{g}$. seemed more effective than smaller doses. One woman received $800 \mu \mathrm{g}$. Although generally improved she complained that she felt "jittery" for a few hours. Several patients experienced a sensation of slight warmth shortly after injection. It seemed possible largely to avoid this effect by using a full minute to inject the hormone. No other sideeffects were noted, and there was no evidence of toxicity due to T.R.H. Other data pertaining to these eight patients have been excluded from the present report.

\section{Patients and Methods}

A double-blind cross-over study against placebo injection was designed. Women between the ages of 25 and 45 admitted to the Dorothea Dix Hospital with primary ${ }^{16}$ unipolar ${ }^{17}$ depression were admitted to the study and transferred to the research unit if they gave informed consent, if they did not use oral contraceptive preparations, if they presented no physical, historical, or chemical evidence of thyroid disorder, and if they were generally in good physical health and were not pregnant. Most patients had taken small amounts of various psychotropic drugs for brief periods of time. We stopped these medications and then gave thrice daily two capsules of placebo which matched imipramine. If, after 7-10 days of placebo medication and general care, the patient still scored substantially on the Hamilton rating scale for depression (H.R.S.) (18), the patient was assigned to group A (five patients) or group B (five patients) according to a prearranged schedule balanced for age. We did not distinguish between the various possible descriptive subtypes of unipolar depression because such distinctions have not been useful in our previous studies.

Group A patients were treated as follows. After baseline assessments, the patient lay supine in bed. A continuous intravenous infusion was begun in one arm; a blood-pressure cuff was attached to the other arm. At 9 A.M., 2 hours after breakfast, $600 \mu$ g. T.R.H. was slowly injected into the intravenous tubing. At regular intervals blood was withdrawn for later analyses of T.S.H. by specific radioimmunoassay, ${ }^{19}$ thyroxine (T4) iodine, ${ }^{20}$ residual $T 4$ binding space, ${ }^{21}$ and total serum-T3, ${ }^{22}$ baseline samples having been obtained earlier. The nurse giving the injections was in sole possession of the medication code. Apart from the injections she had no immediate responsibility to this group of patients. Another nurse, obtaining blood-pressure and pulse recordings regularly, sat with the patient and conversed or remained silent, according to the patient's wish. The patient was allowed out of bed at noon.

A psychiatrist visited the patient at 8 A.M. and hourly thereafter until 3 P.M., except at 1 P.M. At 3 P.M. he did an H.R.S. assessment and the patient completed the Taylor manifest anxiety scale (T.A.S.). ${ }^{23}$ At each hourly session the psychiatrist asked the patient to perform the $100 \mathrm{~mm}$. line test. (In this test a $100 \mathrm{~mm}$. line is drawn on a sheet of plain paper and one end is identified "As well as I could be", the other end "As depressed as I could be". The patient marks where she stands at the moment of testing. The score, the length in millimetres from the "well" end of the line, is based on the premise that length is analogous to the severity of the depression. ${ }^{24,25}$ ) After each hourly session he immediately dictated the results of a brief, informal mental-status examination and inventory of side-effects. At the end of the study another psychiatrist " blindly " assigned numerical values to transcriptions of the mental-status examinations. His ratings were intended to be analogous to scores from the H.R.S.

Ankle-reflex time ${ }^{26}$ was measured at 3 P.M. on injection days and throughout the study.

A week after the T.R.H. injection, group-A patients repeated the same procedure, except that saline solution was infused in place of T.R.H. The same nurse attended, and blood was taken again regularly, though not all of it was assayed for T.S.H.

Group-B patients were treated in an identical manner, except that saline was injected the first week and T.R.H. the second. No other medication than T.R.H. was used during the project. Only one injection of T.R.H. was given to each patient because we were then uncertain of the safety of repeated doses. Placebo capsules were given throughout.

\section{Results}

Although our number of patients was small, equal cell size and placebo cross-over provided considerable statistical power. We subjected the data to analysis of variance according to Winer's technique for repeated measurements ${ }^{27}$ to examine the baseline inequalities between groups (none was significant), interaction, and order effects. By far the greatest differences were caused by treatments-i.e., by the differential use of T.R.H. and saline solution. To test these differences we employed Seal's multivariate technique using orthogonal vectors. ${ }^{28}$ Data from group A (first injection, T.R.H.) were combined with data from group B (second injection, T.R.H.). These data were then compared with the data from the two groups when saline was administered.

Three different periods after injection were examined according to two objectives and two subjective measures of change. To examine for H.R.S. and T.A.S. changes we used the 3 P.M. scores from the preinjection days as baselines (table I). T.R.H. was superior to saline in five of twelve instances. Saline was never superior to T.R.H.

While examining table $\mathrm{I}$, one should recall that on injection days the $100 \mathrm{~mm}$. line test and the mentalstatus examination were performed seven times (two baseline plus five), while the H.R.S. and the T.A.S. were performed only once. Thus there was agreement between the objective and subjective scales performed frequently and agreement between the objective and subjective scales performed infrequently.

TABLE I-ADVANTAGES OF T.R.H. INJECTION ON VARIOUS MEASURES OF MENTAL STATE FOR VARIOUS PERIODS AFTER INJECTION

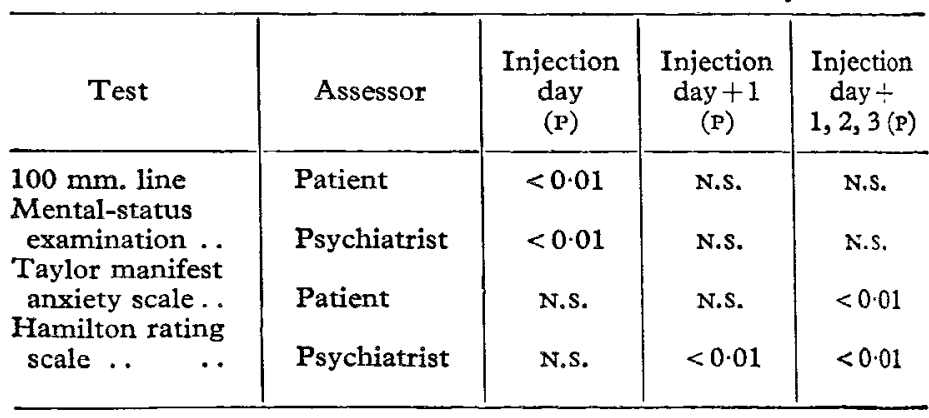

N.s. $=$ Not significant. 
If the hypothalamus is underactive in depression, how does a hypothalamic hormone exert an antidepressant action? A correlation between antidepressant effect and T.S.H. response suggests that the antidepressant effect is mediated by thyroid hormones. The concept is plausible, for T3 alone seems to have antidepressant value. ${ }^{38}$ However, T3 must be given in large doses that speed ankle-reflex time and border on frank toxicity; and our patients showed no increment in thyroid state, chemical or physiological. In any case, the antidepressant effect of T.R.H. need not be thyroid mediated, since Plotnikoff et al. ${ }^{15}$ have shown that T.R.H. will potentiate the behaviour effects of dopa equally in intact mice and hypophysectomised mice.

Conceivably, T.R.H. may bypass the pituitary and exert a direct effect on the thyroid gland, but there is no evidence to suggest this. T.S.H. will potentiate the action of imipramine, and it is possible that endogenous T.S.H., when released after T.R.H. administration, may exert an antidepressant effect. This seems unlikely, the more so because large doses of bovine T.S.H. (given with imipramine) do not cause an antidepressant effect as rapid as the one seen in our trial.12,13 Our patients almost certainly experienced a prolactin release after T.R.H., though this was not measured. We do not know if prolactin has an antidepressant effect or not.

We suggest that T.R.H. has a direct central effect. Consistent with this view is the fact that small amounts of radioactive T.R.H. appear in the hypothalamus of rats after intravenous injection. ${ }^{39}$ The dopa-potentiating effects of T.R.H. and its antidepressant effect are consistent with the catecholamine hypothesis of affective disorders ${ }^{40-42}$ in its generic sense, though Plotnikoff's data may direct attention to dopamine rather than to noradrenaline. Dose-response studies will be needed to clarify the meaning of the correlation of T.S.H. response and antidepressant response. Conceivably, a " high" (i.e., nearly normal) T.S.H. response indicates that a fixed dose of T.R.H. has increased likelihood of restoring the hypothalamus to normal levels of function.

Can T.R.H. be used repeatedly to induce lasting remission in depression? Oral T.R.H. may prove useful. The work of Staub et al. ${ }^{43}$ suggests that the hormone given by mouth has a prolonged action. We are also interested in the possibility of T.R.H. being useful in Parkinson's disease. L-dopa (levodopa) is useful in this condition, and T.R.H. potentiates the central effects of L-dopa in mice. According to our findings, in man T.R.H. has an effect, probably central, that is compatible with $\mathrm{L}$-dopa potentiation.

Papavasiliou et al. ${ }^{44}$ have lately reported the calming and mood-enhancing action of the pineal hormone melatonin in patients with Parkinson's disease. They suggested trials of this substance in mania and depression. It seems possible that brain hormones may in future play a prominent role in the control of behavioural disorders.

Support for this work was provided in part by a U.S. Public Health Service career development award (A. J. P.), by U.S. Public Health Service grants RR-46, HD-03110, MH-15631, a contract from the Food and Drug Administration, and a contract from Abbott Laboratories. We thank Dr. John F. Wilber for assay of T.S.H. Bioscience Laboratories did the T3 assays. Dr. M. S. Anderson, Dr. M. A. Lipton, Dr. R. L. Rollins, Dr. Wilber, and Dr. P. N. Witt provided encouragement and advice.

\section{REFERENCES}

1. Fleischer, N., Burgus, R., Vale, W., Dunn, T., Guillemin, R. F. clin. Endocr. Metab. 1970, 31, 109 .

2. Anderson, M. S., Bowers, C. Y., Kastin, A. J., Schalch, D. S., Schally, A. V., Snyder, P. J., Utiger, R. D., Wilber, J. F., Wise, A. J. New Engl. F. Med. 1971, 285, 1279.

3. Bowers, C. Y., Friesen, H. G., Hwang, P., Guyda, H. J., Folkers, K Biochem. Biophys. Res. Commun. 1971, 45, 1033.

4. Jacobs, L. S., Snyder, P. J., Wilber, J. F., Utiger, R. D., Daughaday, W. H. F. clin. Endocr. Metab. 1971, 33, 966.

5. Prange, A. J., Jr., Wilson, I. C., Rabon, A. M. Excerpta med. int. Congr. Ser. 1968, no. 180, p. 532.

6. Prange, A. J., Jr., Wilson, I. C., Rabon, A. M., Lipton, M. A. Am. F. Psychiat. 1969, 126, 457.

7. Wilson, I. C., Prange, A. J., Jr., McClane, T. K., Rabon, A. M., Lipton, M. A. ibid. p. 457.

8. Wheatley, D. Archs gen. Psychiat. 1972, 26, 229.

9. Coppen, A., Whybrow, P. C., Noguera, R., Maggs, R., Prange, A. J., Jr. ibid. p. 242.

10. Earle, B. V. Am. F. Psychiat. 1970, 126, 1667.

11. Feighner, J. P., King, L. J., Schuckit, M. A., Croughan, J., Briscoe, W. ibid. 1972, 128, 1230 .

12. Prange, A. J., Jr., Wilson, I. C., Knox, A., McClane, T, K., Lipton, M. A. ibid. 1970, 127, 191.

13. Prange, A. J., Jr., Wilson, I. C., Knox, A. E., McClane, T. K., Breese, G. R., Martin, B. R., Alltop, L. B., Lipton, M. A. $f$. psychiat. Res. (in the press).

14. Everett, G. M. Excerpta med. int. Congr. Ser. 1966, no. 122, p. 164.

15. Plotnikoff, N. P., Prange, A. J., Jr., Breese, G. R., Anderson, M. S., Wilson, I. C. Science (in the press).

16. Feighner, J. P., Robins, E., Guze, S. B., Woodruff, R. A., Winokur, G., Munoz, R. Archs gen. Psychiat. 1972, 26, 57.

17. Dunner, D. L., Cohn, C. K., Gershon, E. S., Goodwin, F. K. ibid. $1971,25,348$.

18. Hamilton, M. F. Neurol. Neurosurg. Psychiat. 1960, 23, 56.

19. Odell, W. D., Wilber, J. F., Utiger, R. D. Rec. Progr. Horm. Res. $1967,23,47$.

20. Murphy, B. P. F. Lab. clin. Med. 1965, 66, 161.

21. Mitchell, M. L., Harden, A. B., O'Rourke, M. E. f. clin. Endocr. Metab. 1960, 20, 1474.

22. Pileggi, V. J., Demetriou, J. A., Beattie, J. Scand. J. clin. Lab. invest. 1972, 29, suppl. no. 126, p. 14.

23. Taylor, J. A. F. abnorm. soc. Psychol. 1955, 48, 285.

24. Aitken, R. C. B. Proc. R. Soc. Med. 1969, 62, 989.

25. Zealley, A. K., Aitken, R. C. B. ibid. p. 993.

26. Nuttall, F. Q., Doe, R. P. Ann. intern. Med. 1964, 61, 269.

27. Winer, B. J. Statistical Principles in Experimental Design. New York, 1962.

28. Seal, H. L. Multivariate Statistical Analysis for Biologists. London, 1964.

29. Snyder, P. J., Utiger, R. D. F. clin. Endocr. Metab. 1972, 34, 1096.

30. Snyder, P. J., Utiger, R. D. ibid. p. 380.

31. Clark, F., Horn, D. B. ibid. 1965, 25, 39.

32. Hollander, C. S., Mitsuma, T., Shenkman, L., Woolf, P., Gershengorn, M. C. Science, 1972, 175, 209.

33. Snyder, P. J., Utiger, R. D. F. clin. Invest. 1972, 51, 2077.

34. Azizi, F.g Vangenakis, A. G., Reichlin, S., Braverman, L. E., Ingbar, S. H. Paper read at 48th meeting of American Thyroid Association, 1972; abstr. p. 39.

35. Mueller, P. S., Heninger, G. R., MacDonald, R. K. Archs gen. Psychiat. 1969, 21, 587.

36. Caroll, B. J. Br. med. F. $1969, \mathrm{iii}, 27$.

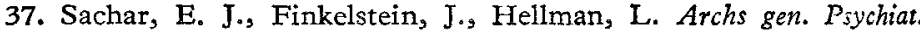
$1971,25,263$.

38. Prange, A. J., Jr, Wilson, I. C. Unpublished.

39. Redding, T. W. Proc. 51st Meet. Endocr. Soc. 1969, abstr. no. 70, p. 65.

40. Schildkraut, J. J. Am. F. Psychiat. 1965, 122, 509.

41. Prange, A. J., Jr. Dis. nerv. System, 1964, 25, 217.

42. Bunney, W. E., Davis, J. M. Archs gen. Psychiat, 1965, 13, 483.

43. Staub, J. J., Weiss, S., Kohler, H., Bürgi, H., König, M. P., Studer, H. Schweiz. med. W schr. 1971, 101, 1295.

44. Papavasiliou, P. S., Cotzias, G. C., Duby, S. E., Steck, A. J. Bell, M., Lawrence, W. H. f. Am. med. Ass. 1972, 221, 89.

\section{Addendum}

Similar results to ours have lately been obtained by Dr. T. M. Itil (personal communication) and by Dr. A. J. Kastin and his colleagues (Lancet, Oct. 7, 1972, p. 740). 